\title{
STUDI LITERATUR: HUBUNGAN PENGETAHUAN DENGAN STIGMA PADA PENDERITA HIV/AIDS (ODHA)
}

\author{
Nila Alfiani, Ahmad Rido’i Yuda Prayogi ${ }^{\bowtie}$, Ayik Mirayanti Mandagi, Diansanto Prayoga \\ Fakultas Kesehatan Masyarakat Universitas Airlangga PSDKU Banyuwangi
}

\begin{tabular}{l}
\hline ARTICLE INFO \\
\hline Article history \\
Submitted : 2021-04-24 \\
Revised : 2021-07-13 \\
Accepted : 2021-07-25 \\
\hline Keywords: \\
HIV \\
Knowledge \\
Stigma
\end{tabular}

\section{Kata Kunci:}

HIV

Pengetahuan

Stigma

\begin{abstract}
HIV/AIDS is a disease that has become a pandemic and worries people all over the world, because until now there has not been found a vaccine or drug for the prevention of HIV/AIDS. HIV positive cases in Indonesia from year to year have increased. The problems faced by people with HIV/AIDS are very complex. Every day the patient's condition will get weaker if he does not take medication regularly because the HIV virus will attack the patient's immune system. In addition, the stigma and discrimination of the surrounding community are also a burden that must be borne by people with HIV AIDS. The stigma makes HIV sufferers worse, with this stigma, HIV sufferers are ashamed to seek treatment at a health service. This writing is to determine the relationship between knowledge and stigma against people living with HIV/AIDS (PLWHA) through a review of various literature with the same theme. The method used in this paper uses rivew literature. This type of research uses systematic review. The study design used retrospective, prospective and systematic review methods. There is a relationship between knowledge and stigma against PLWHA. People with low knowledge tend to stigmatize people with HIV.

HIV/AIDS merupakan penyakit menular yang sampai sekarang belum ada obat untuk menyembuhkan. Terapi Anti Retroviral Virus (ARV) bertujuan untuk memperlambat progresifitas virus sehingga dapat memperpanjang harapan hidup manusia. Kasus HIV positif di Indonesia dari tahun ke tahun mengalami peningkatan. Permasalahan yang dihadapi Orang dengan HIV/AIDS (ODHA) sangat kompleks. Setiap harinya kondisi ODHA akan semakin melemah apabila tidak mengonsumsi obat secara rutin, karena virus HIV akan menyerang kekebalan tubuh penderita. Beban yang harus dipikul oleh ODHA adalah stigma dari masyarakat sekitar. ODHA menjadi malu untuk berobat ke tempat pelayanan Kesehatan, sehingga ODHA tidak mendapatkan penanganan kesehatan. Tujuan penelitian adalah memberikan kajian stigma terhadap orang dengan HIV/AIDS (ODHA) berdasarkan aspek pengetahuan melalui tinjauan berbagai literatur dengan tema yang sama. Metode yang digunakan dalam penulisan ini menggunakan literatur rivew. Jenis penelitian menggunakan systematic review. Desain penelitian digunakan metode retrospektif, prospektif dan tinjauan sistematis. Terdapat hubungan antara pengetahuan dengan stigma terhadap ODHA. Orang y ang berpengetahuan rendah cenderung melakukan stigma terhadap penderita HIV.
\end{abstract}

$\triangle$ Corresponding Author:

Ahmad Rido'i Yuda Prayogi

Fakultas Kesehatan Masyarakat Universitas Airlangga PSDKU Banyuwangi

Telp. 082234354571

Email: ahmad.ridoi.yuda-2017@fkm.unair.ac.id

\section{PENDAHULUAN}

HIV/AIDS merupakan penyakit yang telah menjadi pandemi dan mengkhawatirkan masyarakat seluruh dunia, karena sampai saat ini belum ditemukan vaksin dan obat untuk pencegahan HIV/AIDS. Kasus HIV positif di Indonesia dari tahun ke tahun mengalami peningkatan (Kemenkes RI, 2019). Jumlah kasus pada tahun 2018 dilaporkan terdapat 46.659 kasus. Kasus AIDS yang dilaporkan sebanyak 114.065 kasus pada tahun 2018 (Kemenkes RI, 2019).

Penyakit HIV/AIDS di Indonesia terjadi hampir di seluruh kabupaten, salah satunya di Kabupaten Banyuwangi. Data Dinas Kesehatan Jawa Timur menunjukkan bahwa Banyuwangi berada di posisi ketiga dengan jumlah kasus HIV/AIDS terbesar setelah Surabaya dan Malang pada tahun 2016 (Dinkes, 2017). Setiap tahunnya kasus HIV/AIDS di Banyuwangi mengalami peningkatan dari awal 
kemunculannya tahun 1999 terdapat 1 kasus dan pada tahun 2014 sebanyak 2.140 kasus (Dinkes Banyuwangi, 2017).

Kasus HIV secara global diseluruh dunia mengalami peningkatan selama lima tahun terakhir (World Health Organization, 2018). Kemudian terjadi peningkatan kasus dari tahun 2015 - 2016 sebesar 800.000 kasus, tahun 2016 - 2017 naik sebesar 800.000 kasus, tahun 2017 - 2018 jumlah kenaikan kasusnya sama, yaitu naik 800.000 kasus, dan pada tahun 2018 - 2019 kasus HIV secara global di dunia meningkat sebanyak 700.000 kasus. Kasus HIV terbanyak terjadi di Afrika, yaitu sebanyak 25,7 juta kasus pada tahun 2019 (World Health Organization, 2019).

Permasalahan yang dihadapi penderita HIV/AIDS sangatlah kompleks. Setiap harinya kondisi penderita akan semakin melemah apabila tidak mengonsumsi obat secara rutin karena virus HIV akan menyerang kekebalan tubuh penderita (Retnowati, 2017). Selain itu stigma dan diskriminasi masyarakat sekitar juga menjadi beban yang harus dihadapi oleh penderita HIV/AIDS (Workowski and Bolan, 2015; Sofia, 2018; Timor Leste Demographic Health Survey, 2018). Stigma terhadap ODHA merupakan perlakuan negatif seseorang ketika bertemu dengan ODHA (Shaluhiyah, Musthofa and Widjanarko, 2015). Stigma yang negatif dari masyarakat akan membuat kondisi penderita semakin buruk. Stigma negatif pada penderita akan membuatnya malu untuk melakukan pegobatan dan melakukan tes VCT, sehingga penderita HIV tidak mendapat penanganan yang serius (Retnowati, 2017).

Bentuk dari stigma masyarakat yang diberikan terhadap penderita HIV yaitu dengan dikucilkan, penolakan untuk perawatan pasien HIV, alat makan yang dipisahkan, dikeluarkan dari sekolah, pemutusan hubungan kerja, dan lain sebagainya (Parut, 2016). Stigma terhadap pasien HIV/AIDS tidak hanya diberikan oleh masyarakat, tetapi petugas kesehatan (dokter dan perawat) juga ikut memberikan stigma terhadap penderita HIV/AIDS (Sofia, 2018).

Stigma terhadap ODHA memberikan dampak yang negatif (Pian, 2011; Situmeang, Syarif and Mahkota, 2017; Prayogi et al., 2020). Stigma dilakukan oleh semua kalangan mulai dari orang biasa sampai petugas kesehatan, maka dari itu studi ini bertujuan untuk mengetahui hubungan antara pengetahuan dengan stigma terhadap orang dengan HIV/AIDS (ODHA) dengan mengunakan metode literatur riview.

\section{BAHAN DAN METODE \\ Jenis Studi}

Jenis studi menggunakan systematic review. Desain penelitian digunakan metode retrospektif, prospektif dan tinjauan sistematis.

\section{Waktu Studi}

Artikel yang digunakan adalah artikel nasional dan internasional. Pencarian artikel dimulai pada tanggal 16 Agustus - 20 September 2020.

\section{Pengumpulan Data}

Pengumpulan data studi menggunakan metode review artikel dengan mengumpulkan beberapa artikel yang sesuai dengan kata kunci kemudian dijadikan sebagai hasil dan menjadi pembahasan pada studi. Data base yang digunakan dalam pencarian literatur review yaitu google scholar, Pubmed, dan Science Direct. Kata kunci yang digunakan diantaranya HIV/AID, stigma, masyarakat, pengetahuan, ODHA, dan Banyuwangi.

Kriteria inklusi studi diantaranya artikel yang terbit pada jurnal nasional dan internasional, studi penelitian pada manusia, dan dapat diakses secara gratis. Kriteria eksklusi diantaranya studi pada hewan, jurnal dengan publikasi berbayar, terbit pada tahun < 2005 dan tidak sesuai dengan tujuan penelitian. Penelitian ini mencari daftar referensi dari penelitian yang meliputi: 143 studi diambil melalui pencarian. Sebanyak 63 artikel dalam pembersihan, dan ada 7 artikel yang termasuk dalam Diskusi. Setelah itu dilakukan tinjauan sistematis bersama tim studi terhadap pertanyaan yang dirumuskan secara jelas yang menggunakan sistematik dan eksplisit metode untuk mengidentifikasi, memilih, dan menilai secara kritis penelitian yang relevan, dan untuk mengumpulkan dan menganalisis data dari studi yang termasuk dalam review.

\section{HASIL PENELITIAN}

Hermawati mengatakan bahwa stigma merupakan ciri negatif yang diberikan masyarakat dan dipengaruhi oleh lingkungan (Pian, 2011). Stigma dapat mendorong seseorang mempunyai prasangka, perilaku oleh pihak pemerintah, masyarakat, pemberi kerja, penyedia pelayanan kesehatan, teman kerja, teman, dan keluarga. Bentuk stigma antara lain: 
penolakan oleh teman, keluarga, atau masyarakat terhadap ODHA, pelecehan terhadap ODHA, menjauhi peralatan yang sama dengan peralatan yang digunakan ODHA, tidak mau melibatkan ODHA dalam sebuah organisasi (Parut, 2016).

\section{Tabel 1. Hasil Kajian Hubungan Pengetahaun dengan Stigma pada Penderita HIV/AIDS (ODHA)}

\begin{tabular}{|c|c|c|c|c|}
\hline Peneliti & Metode & Analisis & Sampel & Hasil \\
\hline $\begin{array}{l}\text { Misrina } \\
\text { Retnowati } \\
\text { (2017) }\end{array}$ & $\begin{array}{c}\text { Analitik } \\
\text { korelasional } \\
\text { dengan } \\
\text { pendekatan } \\
\text { cross sectional }\end{array}$ & $\begin{array}{c}\text { Analis data } \\
\text { univariat dengan } \\
\text { distribusi } \\
\text { frekuensi dan } \\
\text { analis a bivariat } \\
\text { secara analitik } \\
\text { dipakai uji chi } \\
\text { square }\end{array}$ & $\begin{array}{l}\text { Sampel merupakan } \\
\text { tokoh agama di } \\
\text { kabupaten Banyumas } \\
\text { yang berjumlah } 164 \\
\text { orang diambil } \\
\text { berdasarkan rumus } \\
\text { slovin }\end{array}$ & $\begin{array}{c}\text { Berdasarkan uji X2 } \\
\text { diperoleh nilai p sebesar } \\
0,000 \text {. Hal ini membuktikan } \\
\text { bahwa ada hubungan antara } \\
\text { pengetahuan dengan stigma } \\
\text { tokoh agama terhadap } \\
\text { ODHA (nilai p<0,05). }\end{array}$ \\
\hline $\begin{array}{l}\text { Ansemus } \\
\text { Aristo Parut } \\
\text { (2016) }\end{array}$ & $\begin{array}{l}\text { Observasional } \\
\text { analisis dengan } \\
\text { design cross- } \\
\text { sectional }\end{array}$ & $\begin{array}{c}\text { uji korelasi } \\
\text { pearson }\end{array}$ & $\begin{array}{l}\text { Sampel adalah murid } \\
\text { SMK VI Surabaya } \\
\text { sejumlah } 74 \text { orang. }\end{array}$ & $\begin{array}{c}\text { Berdasarkan uji statistik } \\
\text { menggunakan korelasi } \\
\text { pearson, diperoleh hasil } \\
\text { koefisien korelasi }-0,890 \\
\text { yang berarti bahwa terdapat } \\
\text { hubungan korelasi negatif } \\
\text { yang sangat kuat antara } \\
\text { pengetahuan dan stigma } \\
\text { terhadap ODHA pada siswa } \\
\text { kelas XI SMKN VI } \\
\text { Surabaya }\end{array}$ \\
\hline $\begin{array}{c}\text { Berliana } \\
\text { Situmeanga } \\
\text { et all (2017) }\end{array}$ & $\begin{array}{c}\text { Analitik } \\
\text { observasional } \\
\text { dengan desain } \\
\text { cross sectional }\end{array}$ & $\begin{array}{c}\text { Analisa univariat } \\
\text { dengan tabulasi } \\
\text { distribusi } \\
\text { frekuensi masing- } \\
\text { masing variabel; } \\
\text { analis a bivariat } \\
\text { dengan tabulasi } \\
\text { silang antara } \\
\text { variabel } \\
\text { independen, } \\
\text { variabel kovariat } \\
\text { dengan variabel } \\
\text { dependen, } \\
\text { dilanjutkan } \\
\text { analisa } \\
\text { stratifikasi. } \\
\text { Analisis } \\
\text { multivariat } \\
\text { menggunakan cox } \\
\text { regression yang } \\
\text { dimodifikasi. }\end{array}$ & $\begin{array}{c}\text { Sampel remaja usia } \\
15 \text { - } 19 \text { tahun yang } \\
\text { sudah pernah } \\
\text { mendengar tentang } \\
\text { HIV/AIDS dan } \\
\text { pernah bersekolah, } \\
\text { sedangkan kriteria } \\
\text { eksklusi data missing. }\end{array}$ & $\begin{array}{l}\text { Nilai PR sebesar } 1,216 \text { ( } 95 \% \\
\text { CI: } 1,183-1,250) \text {. Hal ini } \\
\text { menunjukkan bahwa } \\
\text { kelompok responden yang } \\
\text { memiliki pengetahuan yang } \\
\text { kurang tentang HIV/AIDS } \\
1,216 \text { kali lebih berisiko } \\
\text { mempunyai stigma terhadap }\end{array}$ \\
\hline $\begin{array}{l}\text { Nurma et all } \\
\text { (2018) }\end{array}$ & $\begin{array}{c}\text { Penelitian } \\
\text { observasional } \\
\text { analitik ini } \\
\text { menggunakan } \\
\text { desain cross } \\
\text { sectional. }\end{array}$ & Uji chi-square & $\begin{array}{c}\text { Masyarakat } \\
\text { Kecamatan } \\
\text { Dewantara } \\
\text { Kabupaten Aceh } \\
\text { Utara berusia } \geq 18 \\
\text { tahun, dapat } \\
\text { berkomunikasi } \\
\text { dengan jelas dan }\end{array}$ & $\begin{array}{c}\text { Faktor yang paling } \\
\text { berhubungan dengan } \\
\text { diskriminasi terhadap } \\
\text { ODHA setelah dilakukan } \\
\text { penyesuaian terhadap } \\
\text { variabel pengetahuan dan } \\
\text { social ekonomi (pendidikan } \\
\text { dan pekerjaan) adalah }\end{array}$ \\
\hline
\end{tabular}




\begin{tabular}{|c|c|c|c|c|}
\hline Peneliti & Metode & Analisis & Sampel & Hasil \\
\hline & & & $\begin{array}{l}\text { dapat dipahami oleh } \\
\text { peneliti, bukan } \\
\text { penderita HIV-AIDS, } \\
\text { bersedia menjadi } \\
\text { responden } \\
\text { (menandatangani } \\
\text { informed consent) }\end{array}$ & komunikasi dan moral. \\
\hline $\begin{array}{l}\text { Tri Paryati et } \\
\text { all (2017) }\end{array}$ & Studi Literatur & & & $\begin{array}{l}\text { Stigma dan diskriminasi } \\
\text { terhadap ODHA muncul } \\
\text { berkaitan dengan } \\
\text { ketidaktahuan tentang } \\
\text { mekanisme penularan HIV, } \\
\text { sekitar } 40 \text { sampai } 50 \% \\
\text { masyarakat percaya bahwa } \\
\text { HIV dapat ditularkan } \\
\text { melalui percikan bersin atau } \\
\text { batuk, minum dari gelas } \\
\text { yang sama, dan pemakaian } \\
\text { toilet umum, sedangkan } \\
\text { 20\% percaya bahwa ciuman } \\
\text { pipi bisa menularkan HIV, } \\
\text { pendidikan merupakan salah } \\
\text { satu faktor yang dapat } \\
\text { mempengaruhi munculnya } \\
\text { stigma dan diskriminasi } \\
\text { terhadap ODHA. }\end{array}$ \\
\hline $\begin{array}{c}\text { Ossie } \\
\text { Sosodoro et } \\
\text { all (2009) }\end{array}$ & $\begin{array}{c}\text { Analitik dengan } \\
\text { rancangan cross } \\
\text { sectional }\end{array}$ & $\begin{array}{l}\text { Uji chi-square } \\
\text { dan regresi } \\
\text { logistik }\end{array}$ & $\begin{array}{c}\text { Sampel dalam } \\
\text { penelitian ini adalah } \\
\text { pelajar kelas II SMA } \\
\text { Negeri 4, SMA } \\
\text { Negeri 8, SMA } \\
\text { Bopkri I, dan SMA } \\
\text { Kristen II Kota } \\
\text { Surakarta. }\end{array}$ & $\begin{array}{c}\text { Terdapat hubungan yang } \\
\text { bermakna dengan stigma } \\
\text { ODHA. } \\
\text { Variabel tersebut adalah } \\
\text { pengetahuan tentang } \\
\text { HIV/AIDS (OR=3,37) dan } \\
\text { jenis kelamin } \\
(\mathrm{OR}=1,48) \text {. }\end{array}$ \\
\hline $\begin{array}{l}\text { Monica } \\
\text { Arum M } \\
(2017)\end{array}$ & $\begin{array}{c}\text { Deskriptif } \\
\text { analitik dengan } \\
\text { pendekatan } \\
\text { waktu cross- } \\
\text { sectional. }\end{array}$ & $\begin{array}{c}\text { Distribusi } \\
\text { frekuensi dan chi- } \\
\text { square. }\end{array}$ & $\begin{array}{l}\text { Orang dengan HIV } \\
\text { sebanyak } 86 \\
\text { responden dengan } \\
\text { menggunakan teknik } \\
\text { pengambilan sampel } \\
\text { purposive sampling. }\end{array}$ & $\begin{array}{c}\text { Variabel yang } \\
\text { berhubungan dengan } \\
\text { stigma yaitu, umur, jenis } \\
\text { kelamin, agama, } \\
\text { pendidikan, pekerjaan, } \\
\text { lamanya terinfeksi HIV } \\
\text { dan dukungan keluarga. } \\
\text { Sedangkan variabel yang } \\
\text { tidak berhubungan dengan } \\
\text { stigma yaitu, status } \\
\text { pernikahan, sumber } \\
\text { informasi dan akses } \\
\text { terhadap ARV }\end{array}$ \\
\hline
\end{tabular}

\section{PEMBAHASAN}

Menurut Retnowati, (2017) dalam penelitiannya yang dilakukan pada tokoh agama menyatakan bahwa pengetahuan berhubungan dengan adanya stigma terhadap ODHA. Pernyataan tersebut dibuktikan dengan hasil uji $\mathrm{X} 2$ diperoleh nilai $\mathrm{p}$ sebesar 0,000 . Stigma terhadap ODHA muncul akibat dari ketidaktahuan mekanisme penularan HIV yang benar (Ardani and Handayani, 2017). Masyarakat beranggapan penularan HIV bisa melalui hanya dengan melakukan jabat tangan dengan penderita. 
Penularan HIV secara umum melalui cairan tubuh penderita (sperma dan darah) (Simanjuntak, 2010; Pratiwi and Basuki, 2012). Virus HIV masuk ke dalam tubuh dengan cara pemakaian jarum suntik narkoba secara bergantian, dari ibu ke anak melalui proses persalinan normal, transfusi darah, darah penderita terkena luka di tubuh, dan melakukan hubungan seksual tidak aman (Simanjuntak, 2010).

Penelitian yang dilakukan oleh (Parut, 2016) memiliki hasil yang sama yaitu pengetahuan berhubungan terhadap stigma penderita ODHA. Penelitian ini dikuatkan dengan uji koefisien korelasi dengan diperoleh angka 0,890. Timbulnya stigma terhadap ODHA karena HIV disebabkan sex tidak aman, serta penyalahgunaan narkotika (Parut, 2016).

Masyarakat beraggapan bahwa sex tidak aman hanya dilakukan dengan bergonta ganti pasangan (Fau, Sumardiani Y., Nasution, Zuraiah, Hadi, 2019). Hal tersebut membuat masyarakat memberi nilai negatif terhadap ODHA. Sex tidak aman merupakan sex yang tidak menggunakan pengaman atau kondom (Pratiwi and Basuki, 2012).

Situmeang, Syarif and Mahkota, (2017) mengungkapkan bahwa responden yang memiliki pengetahuan yang kurang tentang HIV/AIDS 1,216 kali lebih berisiko mempunyai stigma terhadap orang dengan HIV/AIDS. Responden yang sering terpapar informasi HIV memiliki pengetahuan yang lebih baik serta tidak memberikan stigma buruk terhadap ODHA (Situmeang, Syarif and Mahkota, 2017).

Hasil penelitian yang dilakukan oleh (Nurma, 2018) menyatakan bahwa faktor yang paling berhubungan dengan diskriminasi terhadap ODHA adalah komunikasi dan moral. Komunikasi bermakna cara seseorang memperoleh informasi. Informasi yang didapat salah maka pengetahun seseorang juga akan berbeda yang nantinya perilaku atau tindakan terhadap ODHA juga akan berbeda (Nurma, 2018).

Paryati et al, (2013) mengungkapkan bahwa 40 sampai $50 \%$ masyarakat percaya bahwa HIV dapat ditularkan melalui percikan bersin atau batuk, minum dari gelas yang sama, dan pemakaian toilet umum, sedangkan $20 \%$ percaya bahwa ciuman pipi bisa menularkan HIV. Hal tersebut merupakan pengetahuan yang salah dan menunjukkan masih rendahnya pengetahuan masyarakat (Paryati et al., 2013). Pengetahuan yang rendah merupakan salah satu faktor yang dapat mempengaruhi munculnya stigma dan diskriminasi terhadap ODHA (Paryati et al., 2013).

Sosodoro, Emilia and Wahyuni (2009) menyatakan bahwa pengetahuan dengan stigma terhadap ODHA memiliki hubungan yang bermakna. Pernyataan tersebut dikuatkan dengan hasil uji regresi logistik dengan $\mathrm{OR}=3,37$. Responden yang berpengetahuan rendah memiliki informasi yang salah seperti salah dalam menggambarkan kondisi fisik penderita HIV, dan sebagian masih belum percaya bahwa kondom dapat mencegah penyebaran HIV/AIDS (Sosodoro, Emilia and Wahyuni, 2009).

Hasil yang berbeda diungkapkan oleh (Mawarni, 2017) yang menyatakan bahwa variabel yang berhubungan dengan stigma terhadap ODHA tidak hanya pengetahuan, namun juga umur, jenis kelamin, agama, pekerjaan, lamanya terinfeksi HIV dan dukungan keluarga. Sedangkan variabel yang tidak berhubungan dengan stigma yaitu, status pernikahan, sumber informasi dan akses terhadap ARV. Pengetahuan bukanlah hal utama yang menimbulkan stigma tehadap ODHA.

\section{KESIMPULAN DAN SARAN}

Pengetahuan memiliki hubungan yang erat dengan stigma terhadap orang dengan HIV/AIDS. Sesuai dari beberapa literatur penelitian yang menyatakan hasil adanya hubungan pengetahuan dengan stigma. Orang yang memiliki pengetahuan rendah cenderung memberikan stigma negatif terhadap ODHA. Mereka tidak mengetahui cara penularan HIV yang benar sehingga mereka tidak mau berdekatan dengan penderita HIV.

Saran yang dapat diberikan bagi pemerintah untuk meningkatkan pengetahuan masyarakat terkait HIV/AIDS dan ODHA baik melalui sosialisasi langsung atau penyebaran informasi melalui media. Bagi masyarakat untuk tidak menghina ODHA, karena yang benar adalah jauhi penyakitnya bukan orangnya. Artinya kita harus saling mendukung agar tidak berbuat salah, sehingga tidak sampai terkena penyakit HIV/AIDS.

DAFTAR PUSTAKA

Ardani, I. and Handayani, S. (2017) 'Stigma 
terhadap Orang dengan HIV/AIDS (ODHA) sebagai Hambatan Pencarian Pengobatan: Studi Kasus pada Pecandu Narkoba Suntik di Jakarta', Buletin Penelitian Kesehatan, 45(2), pp. 81-88.

Dinkes Banyuwangi. (2017) 'Profil Kesehatan Kabupaten Banyuwangi Tahun 2016', Profil Kesehatan, p. 32.

Fau, Sumardiani Y., Nasution, Zuraiah, Hadi, A. J. (2019) 'Stigma Masyarakat Terhadap Orang Dengan HIV/AIDS (ODHA) Di Kabupaten Aceh Utara', The Indonesian Journal of Health Promotion, 2(2), p. 165.

Kemenkes RI (2019) Profil Kesehatan Indonesia 2018 [Indonesia Health Profile 2018].

Mawarni, M. A. (2017) 'Analisis faktor yang berhubungan dengan stigma pada orang dengan HIV (ODHIV) di Kota Yogyakarta', Jurnal Ilmu Kesehatan, pp. 3-19.

Nurma, D. (2018) 'Penyebab Diskriminasi Masyarakat kecamatan Dewantara kabupaten Aceh Utara terhadap Orang dengan HIV-AIDS', SEL Jurnal Penelitian Kesehatan, 5(1), pp. 1-19.

Parut, A. (2016) 'Hubungan Pengetahuan Tentang HIV/AIDS dengan Stigma terhadap ODHA pada Siswa Kelas XI SMK VI Surabaya', Jurnal Ners Lentera, 4(2), pp. 106-113.

Paryati, T. et al. (2013) 'Faktor-faktor yang Mempengaruhi Stigma dan Diskriminasi kepada ODHA (Orang dengan HIV/AIDS) oleh petugas kesehatan: kajian literatur', Pustaka Unpad, (38), pp. 1-11.

Pian, H. (2011) 'Hubungan Persepsi Odha Terhadap Stigma HIV/AIDS Masyarakat dengan Interaksi Sosial pada ODHA [Skripsi]', Jurnal Psikologi.

Pratiwi, N. and Basuki, H. (2012) 'Hubungan Karakteristik Remaja Terkait Risiko Penularan HIV-AIDS dan Perilaku Seks Tidak Aman Di indonesia', Buletin Penelitian Sistem Kesehatan, 14(4 Okt).

Prayogi, A. R. Y. et al. (2020) 'Determining Of Student Depression Level In The Covid19 Pandemic Period (Case Study Of Airlangga University Students, Surabaya)', Journal of Community Mental Health and Public Policy, 4(1), pp. 1-7.
Retnowati, M. (2017) 'Faktor-faktor yang Mempengaruhi Stigma dan Diskriminasi kepada ODHA (Orang dengan HIV/AIDS) oleh petugas kesehatan: kajian literatur', ilmiah kebidanan, 8, pp. 86-94.

Shaluhiyah, Z., Musthofa, S. B. and Widjanarko, B. (2015) 'Stigma Masyarakat terhadap Orang dengan HIV/AIDS', Kesmas: National Public Health Journal, 9(4), p. 333.

Simanjuntak, E. (2010) 'Analisis Faktor Resiko Penularan HIV/AIDS Di Kota Medan', Jurnal Pembangunan Manusia, 4(12), pp. 1-8.

Situmeang, B., Syarif, S. and Mahkota, R. (2017) 'Hubungan Pengetahuan HIV/AIDS dengan Stigma terhadap Orang dengan HIV/AIDS di Kalangan Remaja 15-19 Tahun di Indonesia (Analisis Data SDKI Tahun 2012)', Jurnal Epidemiologi Kesehatan Indonesia, 1(2), pp. 35-43.

Sofia, R. (2018) 'Stigma Dan Diskriminasi Terhadap Odha (Studi Pada Tenaga Kesehatan Di Puskesmas Tanah Pasir Aceh Utara)', AVERROUS: Jurnal Kedokteran dan Kesehatan Malikussaleh, 2(1), p. 79.

Sosodoro, O., Emilia, O. and Wahyuni, B. (2009) 'Hubungan Pengetahuan Tentang HIV/AIDS dengan Stigma Orang dengan HIV/AIDS di Kalangan Pelajar SMA', Berita Kedokteran Masyarakat, 25(4), pp. 210-217.

Timor Leste Demographic Health Survey (2018) Timor Leste demographic and health survey 2016. Dili, Timor Leste.

Workowski, K. A. and Bolan, G. A. (2015) 'Sexually transmitted diseases treatment guidelines, 2015', MMWR Recommendations and Reports.

World Health Organization (2018) 'GHO | By category | Number of people (all ages) living with HIV-Estimates by WHO region', Who.

World Health Organization (2019) 'WHO| Data and statistics', Global update on the health sector responce to HIV. 